\title{
ANALISIS KESULITAN SISWA DALAM MENYELESAIKAN SOAL RELASI MENGGUNAKAN CERTAINTY OF RESPONSE INDEX (CRI)
}

\author{
Margaretha E Kefi ${ }^{1 *}$, Hermina Disnawati ${ }^{2}$, Sulasri Suddin ${ }^{3}$ \\ 1,2,3Prodi Pendidikan Matematika Fakultas Ilmu Pendidikn, Universitas Timor \\ Jalan Km 09 Kelurahan Sasi, Kefamenanu, Indonesia \\ e-mail: 1elmalindatefakefi@gmail.com; ${ }^{2}$ disnawati@unimor.ac.id; ${ }^{3}$ sulasri.suddin@gmail.com; \\ Submitted: July 13,2021 Revised: August 14, 2021 \\ Accepted: August 22, 2021 \\ corresponding author*
}

\begin{abstract}
Abstrak
Penelitian ini bertujuan untuk mengetahui bentuk-bentuk kesulitan siswa dalam menyelesaikan soal relasi berdasarkan kriteria Certainty of Response Index (CRI) yaitu siswa yang tidak paham konsep karena menebak (lucky guess), tidak paham konsep karena kurangnya pengetahuan (a lack of knowlegde) dan mengalami miskonsepsi. Penelitian diskriptif kualitatif ini menggunakan metode tes dan wawancara untuk memperoleh data bentuk kesulitan siswa. Subjek penelitian melibatkan siswa kelas VIII yang telah mempelajari materi relasi. Hasil penelitian menunjukan bahwa pada CRI kategori lucky guess terdapat 11 variasi kesulitan siswa, kategori a lack of knowledge terdapat 10 variasi jawaban dan kriteria miskonsepsi terdapat 14 variasi kesulitan siswa. Selain itu, siswa lebih banyak mengalami kesulitan dalam menerapkan prinsip daripada kesulitan dalam mempelajari konsep. Jenis kesulitan dalam memahami prinsip kriteria paham konsep lucky guess terdapat 9 variasi, dan kriteria paham konsep a lack of knowlegde terdapat 9 variasi dan kriteria miskonsepsi terdapat 18 variasi.
\end{abstract}

Kata Kunci: CRI, kesulitaan siswa, variasi jawaban, relasi

\section{ANALYSIS OF STUDENT DIFFICULTIES IN SOLVING RELATIONS PROBLEMS USING CERTAINTY OF RESPONSE INDEX (CRI)}

\begin{abstract}
This study aims to determine the forms of students' difficulties in solving relations problems based on the Certainty of Response Index (CRI) criteria, namely students who do not understand the concept (lucky guess), do not understand the concept (a lack of knowledge) and misconceptions. This qualitative descriptive research uses test and interview methods to obtain data on student difficulties. The subjects of this study were students of class VIII who had studied relations topics. The results showed that based on the CRI criteria on the type of difficulty in understanding the concept of the CRI criteria understanding the lucky guess concept, there were 11 variations. The criteria for understanding a lack of knowledge were ten variations, and the misconception criteria were 14 variations. Moreover, most of the students had difficulties in applying principal matters than understanding the concept of relations.
\end{abstract}

Keywords: CRI, student's difficulties, answer variation, relations

\section{Pendahuluan}

Matematika adalah salah satu mata pelajaran yang penting untuk dipelajari dan diajarkan dalam dunia pendidikan sejak usia dini hingga perguruan tinggi dalam upaya meningkatkan mutu pendidikan. Matematika diperlukan oleh peserta didik untuk memenuhi kebutuhan guna memecahkan masalah dalam kehidupan seharihari, misalnya dapat mengoperasi perhitungan seperti penjumlahan, pengurangan, perkalian maupun pembagian, serta dapat mengaplikasikan konsep dan lain sebagainya. Proses pembelajaran disekolah, matematika merupakan salah satu mata pelajaran yang menjadi sorotan para guru.

Matematika menjadi sorotan karena masih banyak siswa yang menganggap bahwa matematika itu membosankan dan tidak menarik pelajaran matematika dirasakan sukar dan rumit. Kerumitan Matematika sesuai dengan pernyataan Sari dan Surya (2017) yang menyatakan bahwa siswa pada umumnya tidak menyukai matematika karena dipandang sebagai sesuatu yang sulit dan membosankan. Pernyataan ini merupakan hal negatif terhadap pembelajaran matematika, dengan 
demikian minat belajar siswa semakin berkurang sehingga mengakibatkan siswa mengalami kesulitan dalam menyelesaikan masalah matematika. Kesulitan-kesulitan yang dialami siswa dalam belajar matematika menyebabkan siswa sering melakukan kesalahan dalam menyelesaikan setiap tahapan soal yang diberikan. Kesalahan yang dilakukan siswa pada umumnya disebabkan karena kesulitan dalam memahami konsep, prinsip, maupun kesulitan dalam memahami maksut dari pernyataan soal. Hasil penelitian yang telah dilakukan oleh Nurjana dan Sujadi (2018) bahwa siswa sulit dalam memahami konsep, kesulitan dalam penggunaan prinsip, kesulitan dalam menyatakan informasi dari soal, dan kesulitan dalam melakukan operasi perhitungan.

Salah satu pokok bahasan matematika jenjang SMP adalah relasi. Materi relasi sangat membutuhkan ketelitian dalam proses menyelesaikan soal. Memahami materi relasi matematika. Siswa diharapkan benar-benar menguasai konsep yang dipelajari akan digunakan untuk pembelajaran materi berikutnya.

Berdasarkan hasil observasi yang telah dilakukan pada salah satu siswa SMPN Oenenu bahwa siswa tidak memahami soal sehingga hasil jawaban siswa tidak sesuai dengan pernyataan soal. Sumber kesulitan dalam memahami sebuah konsep bisa bersumber pada siswa atau dalam diri pengajar yang disalurkan kepada siswa. Kesulitan-kesulitan siswa dalam memahami konsep, akan diteliti lebih lanjut dengan menanyakan secara mendalam, tentang proses berpikir dan alasan siswa dalam menyelesaikan soal-soal materi relasi matematika, sehingga diperoleh informasi terkait miskonsepsi yang mendasari karena kesulitan siswa dalam menyelesaikan soal.

Suatu cara mendeteksi terjadinya miskonsepsi dengan menggunakan (Certainty of Response Index) CRI. CRI adalah ukuran tingkat keyakinan atau kepastian responden dalam menjawab setiap pertanyaan (soal) yang diselesaikan. Perhitungan CRI didasarkan pada skala mulai dari nol (0) sampai dengan skalah lima (5). Tujuan penelitian ini untuk memaparkan Bentuk-bentuk kesulitan siswa dalam menyelesaikan soal materi relasi berdasarkan kriteria Certainty of response index. Menurut Febrini (2017: 161) Kesulitan belajar adalah gabungan gangguan yang bervariasi berbentuk kesulitan dalam mendapatkan dan menggunakan kemampuan mendengar, berbicara, membaca, berpikir dan berhitung. Menurut Subini (2012: 5758) kesulitan belajar merupakan kondisi dimana prestasi yang diraih tidak sesuai dengan kriteria standar yang telah ditetapkan baik itu sikap, pengetahuan maupun keterampilan. Menurut Wigati, T. U. (2012: 5) macam-macam kesulitan belajar matematika antara lain, kesulitan penggunaan konsep, penggunaan prinsip, mengungkapkan informasi dan berhitung. Menurut pendapat Cooney et al, dalam Yusmin (2017: 2123) bahwa pembelajaran matematika terdapat 3 macam kesulitan yaitu, kesulitan siswa menggunakan konsep, meliputi ketidakmampuan akan mengingat nama-nama sebagai teknis, tidak mampu untuk menyatakan arti istilah yang mewakili konsep tertentu, tidak mampu untuk mengingat suatu kondisi bagi suatu objek untuk menyatakan dengan istilah yang mengwakili konsep tersebut, tidak bisa membagi objek sebagai contoh suatu konsep dari objek yang bukan contohnya, tidak mampu memberikan informasi dari konsep yang diberikan.

Kesulitan siswa dalam menggunakan prinsip meliputi, ketidakmampuan untuk memulai tentang sesuatu dan tidak teliti dalam perhitungan, ketidakmampuan dalam menemukan faktor relevan mengakibantkan siswa tidak mampu untuk menyatakan pola-pola, siswa mampu untuk menyatakan suatu prinsip akan tetapi tidak mampu untuk menyatakan artinya, dan tidak bisa menggunakan prinsip. Kesulitan dalam menyelesaikan masalah verbal.

Metode CRI adalah cara yang digunakan untuk mengukur tingkat keyakinan siswa dari materi yang telah diajarkan oleh guru. CRI adalah ukuran tingkat keyakinan/kepastian responden dalam menjawab setiap pertanyaan yang diberikan. Penggunaan metode CRI ini didasarkan pada skala dan kesempatan untuk menjawab soal. Skala CRI yang digunakan yaitu 0-5, dan diberikan bersamaan dengan setiap jawaban soal Jika CRI rendah menandakan ketidakyakinan siswa dalam menjawab suatu pertanyaan atau bisa diartikan adanya unsur penebakan dalam menjawab soal

Sebaliknya jika CRI tinggi menandakan keyakinan siswa dalam menjawab suatu pertanyaan baik. Jika jawaban yang dijawab benar, maka tingkat keyakinan yang tinggi akan kebenaran konsepnya telah teruji dengan baik. Dalam penggunaan metode CRI ini, cara untuk mengetahui kemampuan siswa yaitu dengan cara memberikan tes pilihan ganda yang bersifat pemahaman konsep. Skala yang digunakan dalam CRI terdapat pada tabel berikut.

Tabel 1. CRI dan Kriteria

\begin{tabular}{cl}
\hline CRI & \multicolumn{1}{c}{ Kriteria } \\
\hline 5 & Certain ( Sangat Paham) \\
\hline 4 & Almost Certain (Hampir Paham) \\
\hline
\end{tabular}




\begin{tabular}{cl}
\hline 3 & Sure (Yakin) \\
\hline 2 & Not Sure (Tidak Yakin) \\
\hline 1 & $\begin{array}{l}\text { Almost Guess (Sebagian Jawaban Menduga- } \\
\text { duga) }\end{array}$ \\
\hline 0 & $\begin{array}{l}\text { Totally Guessed Answer (Keseluruhan } \\
\text { Jawaban Menduga-duga) }\end{array}$ \\
\hline
\end{tabular}

Penggunaan skala CRI ini di saat siswa menjawab soal yang diberikan, dimana siswa diminta memberikan nilai 0-5 disetiap soal yang dijawab. Hasil dari nilai CRI yang diberikan oleh siswa diolah kemudian dipadukan hasilnya dengan kriteria paham atau tidak paham konsep. Berdasarkan tabel tersebut, menurut Hasan (dalam Tayubi, 2005) angka 0 menandakan bahwa siswa tidak tahu atau tidak paham akan konsep yang diajarkan, sedangkan angka 5 menyatakan bahwa siswa paham konsep yang telah diajarkan dan percaya diri dalam menjawab setiap pertanyaan. Untuk skala kepastian 0-2 menandakan bahwa penebakan jawaban yang dilakukan siswa menjadi peran yang penting dalam menjawab soal tidak melihat jawaban itu salah atau benar. Skala 3-5 menandakan bahwa siswa memiliki tingkat kepercayaan yang tinggi dalam menjawab soal, dalam tingkat ini siswa dapat menjawab soal denga nilai yang benar dan menunjukan bahwa siswa paham akan konsep yang diajarkan, tetapi jika jawaban salah terdapat kekeliruan dalam pemahaman konsep.

Tabel 2. Perbedaan Kriteria CRI

\begin{tabular}{cll}
\hline $\begin{array}{c}\text { Kriteria } \\
\text { Jawaban }\end{array}$ & \multicolumn{1}{c}{$\begin{array}{c}\text { CRI Rendah } \\
(<\mathbf{2 , 5})\end{array}$} & \multicolumn{1}{c}{$\begin{array}{c}\text { CRI Tinggi } \\
(>\mathbf{2 , 5})\end{array}$} \\
\hline Jawaban & Jawaban benar & Jawaban benar \\
benar & tapi CRI rendah & tapi CRI tinggi \\
& berarti tidak tahu & berarti menguasai \\
& konsep (lucky & konsep dengan \\
guess $)$ & baik \\
\hline Jawaban & Jawaban salah tapi & Jawaban salah \\
salah & $\begin{array}{l}\text { CRI rendah berarti } \\
\text { tidak tahu konsep }\end{array}$ & tapi CRI tinggi \\
& $\begin{array}{c}\text { a lack of terjadi } \\
\text { knowlegde })\end{array}$ & miskonsepsi \\
\hline
\end{tabular}

Sumber: Hasan (1999)

Tabel di atas menunjukan empat kemungkinan kombinasi dari jawaban (benar atau salah) dan CRI (tinggi atau rendah) untuk setiap responden secara individu dari suatu pertanyaan yang di berikan, jawaban benar dengan CRI rendah menandakan tidak tahu konsep, dan jawaban benar dengan CRI tinggi menunjukan penguasaan konsep yang tinggi. Jawaban salah dengan CRI rendah menandakan tidak tahu konsep, sementara jawaban salah dengan CRI tinggi menandakan terjadinya miskonsepsi. Salah satu materi mata pelajaran matematika disekolah menengah pertama adalah relasi. Materi ini disusun dan diberikan kepada siswa sesuai kurikulum dalam mempelajari matematika, Relasi adalah suatu kalimat matematika yang memasangkan unsur-unsur dari suatu himpunan ke suatu himpunan lain. Relasi dari dua himpunan A ke himpunan B adalah pemasangan anggota himpunan A ke anggota himpunan B. Berdasarkan diagram relasi antara himpunan A dengan himpunan B dinyatakan dengan tanda panah yang memasangkan anggota himpunan A dengan anggota himpunan B. Himpunan pasangan berurutan adalah Suatu relasi juga dapat dinyatakan dengan menggunakan pasangan berurutan yaitu memasangkan atau memetakan himpunan A dengan himpunan B secara berurutan. (Bahtiar, 1990).

\section{Metode Penelitian}

Penelitian diskriptif kualitatif ini menjadikan 3 siswa kelas VIII SMP Negeri Oenenu semester genap tahun ajaran 2020/2021 sebagai subjek yang diteliti. Adapun Teknik pengumpulan data yang digunakan pada penelitian ini menggunakan tes pilihan ganda beralasan berjumlah 5 nomor dan wawancara. Teknik analisis data yang digunakan dalam penelitian ini adalah mengacu pada model Sugiyono (2015) yaitu (1) Mereduksi data (2) Penyajian data (3) Menarik kesimpulan.

\section{Hasil dan Pembahasan}

Tujuan penelitian ini adalah untuk memaparkan bentuk kesulitan siswa dalam menyelesaikan soal relasi berdasarkan kriteria CRI dipilih 3 subjek yang mewakili 1 nomor jawaban benar CRI rendah "Tidak Paham Konsep (lucky guess) 2. Jawaban salah CRI rendah "Tidak Paham Konsep (a lack of knowlegde)" 3. Jawaban salah CRI tinggi "(Miskonsepsi)".

Berdasarkan hasil analisis jawaban siswa dan tingkat keyakinan siswa terhadap soal tes yang diberikan, peneliti mendeskripsikan kombinasi jawaban yang diberikan ber dasarkan nilai kriteria CRI rendah dan nilai CRI tinggi serta menyajikan datanya dalam bentuk tabel dengan perhitungan pada soal yang dianalisis dengan rumus:

Keterangan

$$
P=\frac{F}{N} \times 100 \%
$$

$$
\begin{aligned}
& \mathrm{P} \text { = Angka Persentase } \\
& \mathrm{F} \text { = Jumlah siswa setiap kelompok } \\
& \mathrm{N}
\end{aligned}
$$


Tabel 3. Jenis kesulitan yang dilakukan siswa pada tiap nomor soal

\begin{tabular}{ccccc}
\hline & \multicolumn{4}{c}{ Tipe Kesulitan } \\
\cline { 2 - 5 } Nomor & \multicolumn{2}{c}{ Kesulitan } & \multicolumn{2}{c}{ Kesulitan } \\
Soal & memahami konsep & memahami prinsip \\
\cline { 2 - 5 } & $\begin{array}{c}\text { Frekuen } \\
\text { si }\end{array}$ & Persen & $\begin{array}{c}\text { Frekuen } \\
\text { si }\end{array}$ & Persen \\
\hline 1 & 5 & $31,25 \%$ & 6 & $37,5 \%$ \\
\hline 2 & 6 & $37,5 \%$ & 5 & $31,25 \%$ \\
\hline 3 & 8 & $50 \%$ & 10 & $62,5 \%$ \\
\hline 4 & 9 & $56,25 \%$ & 7 & $43,75 \%$ \\
\hline 5 & 7 & $43,75 \%$ & 8 & $50 \%$ \\
\hline Jumlah & 35 & & 36 & \\
\hline
\end{tabular}

Berdasarkan tabel 3 terlihat bahwa pada soal nomor 1 yang mengalami kesulitan dalam memahami konsep ada 5 siswa dan yang mengalami kesulitan dalam memahami prinsip ada
6 siswa. Sedangkan pada soal nomor 2 terdapat 6 siswa yang mengalami kesulitan dalam memahami konsep dan 5 siswa yang mengalami kesulitan dalam memahami prinsip. Pada soal nomor 3 terdapat 8 siswa mengalami kesulitan dalam memahami konsep, dan 10 siswa mengalami kesulitan dalam memahami prinsip.

Pada soal nomor 4, terdapat 9 siswa yang mengalami kesulitan dalam memahami konsep dan 7 siswa mengalami kesulitan dalam memahami prinsip. Pada soal nomor 5 terdapat 7 siswa yang mengalami kesulitan dalam memahami konsep dan 8 siswa mengalami kesulitan dalam kesulitan memahami prinsip. Secara umum siswa-siswi ratarata lebih banyak mengalami kesulitan dalam memahami prinsip.

Tabel 4. Jenis-jenis Kesulitan Berdasarkan Kriteria CRI

\begin{tabular}{lcccc}
\hline \multicolumn{1}{c}{ Jenis Kesulitan } & $\begin{array}{c}\text { Tidak paham } \\
\text { konsep (lucky } \\
\text { guess) }\end{array}$ & $\begin{array}{c}\text { Tidak paham } \\
\text { konsep (a lack of } \\
\text { knowlegde) }\end{array}$ & Miskonsepsi & Jumlah \\
\hline $\begin{array}{l}\text { Kesulitan memahami } \\
\text { konsep }\end{array}$ & 11 & 10 & 14 & 35 \\
\hline $\begin{array}{l}\text { Kesulitan memahami } \\
\text { prinsip }\end{array}$ & 9 & 9 & 18 & 36 \\
\hline
\end{tabular}

Berdasarkan tabel 4 dapat dijelaskan bahwa siswa yang mengalami kesulitan dalam memahami konsep pada kategori Tidak Paham Konsep (lucky guess) sebanyak 11 variasi, pada kategori Tidak Paham Konsep (a lack of knowlegde) sebanyak 10 variasi dan pada kategori Miskonsepsi sebanyak 14 variasi. Pada kesulitan dalam prinsip pada kategori Tidak Paham Konsep (lucky guess) sebanyak 9 variasi, pada kategori Tidak Paham Konsep (a lack of knowlegde) sebanyak 9 variasi dan pada kategori Miskonsepsi sebanyak 18 variasi.

Pada penelitian ini peneliti menggunakan 1 soal dari 5 soal yang ada, untuk mewakili setiap kriteria CRI.

\section{Siswa $\mathbf{S 7}$ mewakili Jawaban benar CRI rendah Tidak Paham Konsep (lucky guess) Pada soal nomor 1, siswa diminta untuk menentukan daerah hasil relasi dari himpunan A dan B}

Hasil pekerjaan siswa menunjukan bahwa siswa S7 mampu untuk menjawab soal dengan benar, dan mengikuti langkah-langkah yang ada akan tetapi siswa S7 tidak mampu menjelaskan daerah hasil relasi. Siswa S7 termasuk dalam kategori Tidak Paham Konsep (lucky guess) karena dari 5 soal siswa S7 mengalami Jawaban benar CRI rendah terdapat 4 nomor dan jawaban salah CRI rendah terdapat 1 nomor.

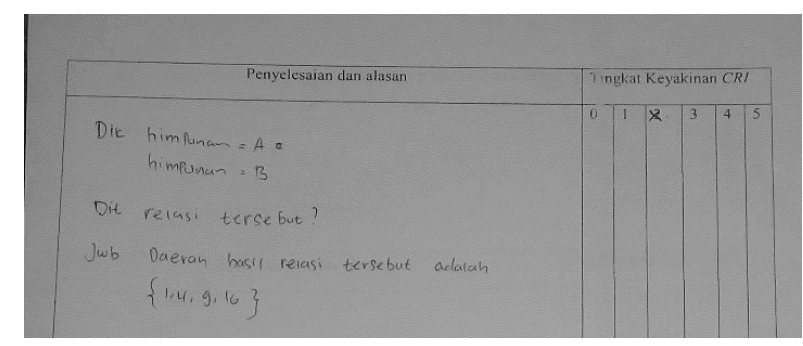

Gambar 1. Hasil kerja siswa S7 nomor 1

Wawancara siswa S-7 dalam menyelesaikan soal nomor 1 tentang tentukan daerah hasil relasi dari himpunan A dan B. Hasil wawancara menyatakan bahwsa siswa S-7 memahami soal yang diberikan dan menyelesaikan soal dengan menggunakan langkah-langkah penyelesaian, akan tetapi siswa S-7 tidak mampu untuk menjelaskan daerah hasil relasi dan pada saat menyelesaikan soal siswa isi saja dan kebetulan jawabanya benar.

Berdasarkan jawaban siswa diatas menunjukan bahwa siswa S7 termasuk dalam kategori jawaban benar CRI rendah Tidak Paham Konsep (lucky guess) dimana siswa S7 mengalami kesulitan dalam memahami prinsip yaitu ketidakmampuan melakukan kegiatan penemuan tentang sesuatu dan tidak teliti dalam perhitungan 
atau operasi aljabar. Hal ini didukung oleh hasil peneltian Dewi (2020) yang menyimpullkan bahwa kesulitan menggunakan prinsp merupakan kesulitan yang paling banyak dialami siswa dalam menyelesaikan soal matematika materi operasi bilangan pecahan.

Siswa S3 mengwakili siswa yang Jawaban salah CRI rendah "Tidak Paham Konsep (a lack of knowlegde)". Pada soal nomor 2 siswa diminta untuk menentukan himpunan pasangan berurutan yang menyatakan relasi "dua lebihnya dari" dari himpunan $K$ dan $L$

Hasil pekerjaan siswa menunjukan bahwa siswa mampu untuk menyelesaikan soal dengan menggunakan langkah-langkah penyelesaian tetapi siswa tidak mampu untuk menjawab soal dengan benar. Siswa S3 juga termasuk dalam kategori Tidak Paham Konsep (a lucky of knowlegde) karena dari 5 soal S3 mengalami Jawaban salah CRI rendah terdapat 3 nomor dan jawaban benar CRI tinggi terdapat 2 nomor.

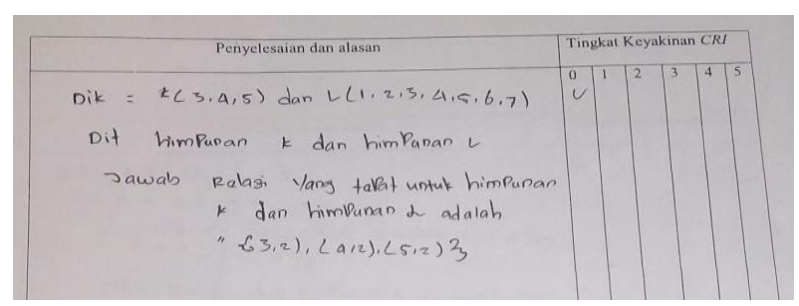

Gambar 2. Hasil kerja siswa S-3 nomor 2

Wawancara siswa S-3 dalam menyelesaikan soal nomor 2 menentukan himpunan pasangan berurutan yang menyatakan relasi "dua lebihnya dari". Hasil wawancara menyatakan bahwa siswa S-3 memahami soal dan siswa dalam menyelesaikan soal dengan menggunakan langkah-langkah, tetapi Ketika ditanya siswa tidak paham pernyataan dari soal.

Berdasarkan jawaban siswa diatas menunjukan bahwa siswa S3 termasuk dalam kategori jawaban salah CRI rendah dimana siswa S3 juga mengalami kesulitan dalam menggunakan prinsip yaitu ketidakmampuan melakukan kegiatan penemuan tentang sesuatu dan tidak teliti dalam perhitungan atau operasi aljabar, hal ini didukung oleh hasil penelitian Dewi (2020) yang menyimpulkan bahwa Kesulitan menggunakan prinsip merupakan kesulitan yang paling banyak dialami siswa dalam menyelesaikan soal.

Siswa S-4 mengwakili siswa yang jawaban salah CRI tinggi “(Miskonsepsi)". Pada soal nomor 3 siswa diminta untuk menentukan relasi dari himpunan $\mathrm{K}$ dan himpunan $\mathrm{L}$

Hasil pekerjaan siswa menunjukan bahwa siswa S-4 tidak mampu untuk menyelesaikan soal dengan menggunakan langkah-langkah penyelesaian dan tidak mampu untuk menyelesaikan soal dengan benar. Siswa S4 juga termasuk dalam kategori jawaban salah CRI tinggi karena dari 5 soal S4 mengalami Jawaban salah CRI tinggi terdapat 4 nomor dan jawaban benar CRI rendah terdapat 1 nomor.

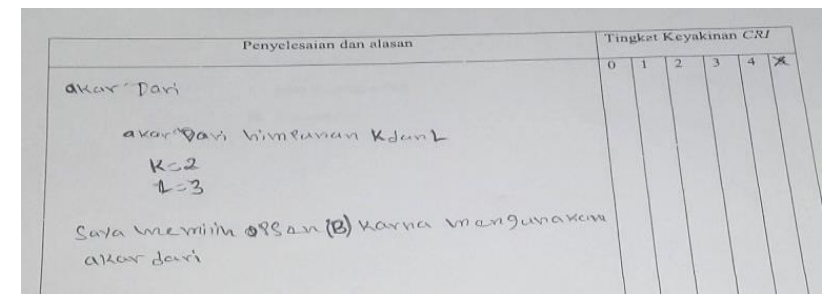

Gambar 3. Hasil jawaban siswa S-4 nomor 3

Wawancara siswa S-4 dalam menyelesaikan soal nomor 3 siswa diminta untuk menentukan relasi dari himpnan $\mathrm{K}$ dan himpunan L. Hasil wawancara menyatakan bahwa siswa S-4 tidak mampu untuk menyelesaikan soal karena siswa S4 tidak paham suruhan dari soal dan tidak menggunakan langkah-langkah penyelesaian dikarenakan siswa tidak paham langkah-langkah dalam menyelesaikan soal.

Berdasarkan jawaban siswa diatas menunjukan bahwa siswa S4 termasuk dalam kategori jawaban salah CRI tinggi dimana siswa S4 juga mengalami kesulitan dalam memahami konsep dan dalam memahami prinsip yaitu ketidakmampuan untuk menyimpulkan informasi dari suatu konsep yang diberikan. Dan ketidakmampuan melakukan kegiatan penemuan tentang sesuatu dan tidak teliti dalam perhitungan atau operasi aljabar. Hal ini didukung oleh hasil penelitian Lithner (2011) yang mengatakan bahwa kesulitan dalam menyelesaikan persoalan matematika materi operasi hitung bilangan pecahan.

\section{Kesimpulan}

Kesulitan-kesulitan yang dilakukan siswa dalam menyelesaikan soal relasi adalah Siswa yang mengalami kesulitan dalam memahami konsep pada kategori Tidak Tahu Konsep (lucky guess) sebanyak 11 variasi, pada kategori Tidak Tahu Konsep (a lack of knowlegde) sebanyak 10 variasi dan pada kategori Miskonsepsi sebanyak 14 variasi. Siswa yang mengalami kesulitan dalam memahami prinsip pada kategori Tidak Tahu Konsep (lucky guess) sebanyak 9 variasi, pada kategori Tidak Tahu Konsep (a lack of knowlegde) sebanyak 9 variasi dan pada kategori Miskonsepsi sebanyak 18 variasi. Dari data diatas dapat disimpulkan bahwa pada kategori Miskonsepsi 
siswa lebih banyak mengalami kesulitan dalam memahami prinsip.

Berdasarkan kesimpulan diatas, penulis memberikan beberapa saran untuk mengatasi siswa yang Tidak Paham Konsep, (lucky guess), Tidak Paham Konsep (a lack of knowlegde), dan Miskonsepsi. Serta kesulitan kesulitan yang dilakukan siswa dalam menyelesaikan soal-soal relasi. Bagi guru dalam proses pembelajaran agar melatih siswa, menyelesaikan soal dengan langkah-langkah, penyelesaian secra lengkap, dan terstruktur. Guru diharapkan memberikan strategi/ model yang digunakan dalam pembelajaran, memberikan motivasi yang lebih kepada siswa untuk belajar dan memberikan apresiasi kepada siswa yang berhasil dalam belajar. Bagi kepala sekolah Memperhatikan proses belajar di sekolah dengan memperbanyak materi dan metode pembelajaran yang dapat meningkatkan kemampuan siswa dalam menyelesaikan soal.

\section{Daftar Pustaka}

Bahtiar Sjarif (1990). Pengantar Dasar Matematika. Fakultas MIPA, ITB. Bandung.

Dewi, N. K., Untu, Z., \& Dimpudus, A. (2020). Analisis Kesulitan MenyelesaikanSoal Matematika Materi Operasi Hitung Bilangan Pecahan Siswa Kelam VII. Primatika: Jurnal Pendidikan Matematika, 9(2), 61-70.

Febrini, (2017). Psikologi Pembelajaran Yogyakarta: Pustaka Belajar. Jakarta: Rineka Cipta.

Hasan, S., Bagayoko, D., \& Kelley, E. L. (1999). Misconceptions and the certainty of response index (CRI). Physics education, 34(5), 294-299.

Hutami, D. P. N. (2018). Analisis Miskonsepsi Siswa Dalam Menyelesaikan Soal Barisan Dan Deret
Berdasarkan Certainty of Response Index (Cri) Ditinjau Dari Gaya Kognitif Reflektif Dan Impulsif.

Lithner, J. (2011). University Mathematics Students' Learning Difficulties. Education Inquiry. Vol 2 (2): 289-303.

Nurjana, S \& Sujadi, A.A (2018). Analisis Kesulitan Siswa dalam Menyelesaikan Soal-Soal Program Linear pada Siswa Kelas X TKJ Smk Piri 2 Yogyakarta. Prosiding Seminar Nasional Pendidikan Matematika Etnpmatnesia.

Sari, \& Surya, E. (2017). Efektivitas Penggunaan Teknik Scffolding dalam Meningkatkan Hasil Belajar Matematika pada Siswa SMP Swasta AL-Washliyah Medan. Education Jurnal Pendidikan Matematika, 7 (1).

Subini, N.D (2012). Psikologi Pendidikan Yogyakarta: Mentari Pustaka.

Sugiyono, (2015), Buku Metode Penelitian dan Pengembangan. Alfabate Bandung

Suparno, P. (2013). Miskonsepsi dan Perubahan Konsep dalam Pendidikan Fisika, Yogyakarta: Gramedia Widiasarana Indonesia.

Tayubi, yuyu. R (2005). Identifikasi Miskonsepsi pada Konsep-Konsep Fisika Menggunakan Certainty of Response Index (CRI).

Wafiyah, N. (2012). Identifikasi Miskonsepsi Siswa Dan Faktor-Faktor Penyebab Pada Materi Permutasi Dan Kombinasi Di Sma Negeri 1 Manyar. Gamatika. II (2): 128-138

Wigati Tri Utami. (2012). Jurnal Skripsi Identifikasi Kesulitan dalam menyelesaikan Persoalan Matematika yang berkaitan dengan Pecahan di kelas VIII SMP N 3 Ngaglik Sleman tahun Ajaran 2011/2012. Yogyakarta: Universitas Negeri Yogyakarta.

Yusmin, E. (2017). Kesulitan Belajar Siswa Pada Pelajaran Matematika (Rangkuman dengan Pendekatan Meta-Ethnogrphy). Jurnal Visi Ilmu Pendidikan. 9(1): 2123 